\title{
DEVELOPING WEB-BASED READING LEARNING MATERIALS FOR GRADE VIII STUDENTS OF SMP NEGERI 8 MEDAN
}

\author{
WINDI ABDILLAH* \\ NORA RONITA DEWI** \\ JULI RACHMADANI HASIBUAN**
}

\begin{abstract}
Abdillah, Windi. Registration Number: 2143121048. Developing Web-based Reading Learning Materials for Grade VIII Students of SMP Negeri 8 Medan. A Thesis. English Educational Program, State University of Medan, 2018.

This study aimed at identifying the needs of grade eight students of SMP Negeri 8 Medan in learning reading English using website and concerns on how web-based reading learning materials are developed for grade VIII students of junior high school. The nature of this study is Research and Development (R \& D). The steps were conducting the needs analysis, writing the course grid, storyboarding, writing the first draft, obtaining the experts' judgments, revising the first draft, and finally writing the final draft. This study involved 32 students of the eight grade students of SMP Negeri 8 Medan as the research subjects. The instruments for collecting the data were questionnaires (needs analysis questionnaire and expert judgment questionnaires). The results of the needs analysis questionnaire were analyzed using percentage and the expert judgment were analyzed using descriptive statistics. Data got from the result of need analysis was being the basis in developing the product. The website was divided into five pages: Home, Start Up, Your Focus, Your Activity, and Grammar Corner. Then, based on the expert judgment, the website are appropriate for the grade eight students of junior high school. It was proved by the mean value of 4.2 for web based materials which cover the appropriateness of content, language, and presentation, and 4.5 for the website.
\end{abstract}

Key words: Research and Development $(R \& D)$, Website, Reading Materials, Junior High School

*Graduate

** Lecturer 


\section{INTRODUCTION}

The Background of the Study

English has become one of the tools to connect people in communicating with each other as it is the international language that covers almost all of aspects in people's life and that is why English is included as a lesson in the curriculum in Indonesia. In the national education curriculum in Indonesia, students learn English as a foreign language. They only learn English in the classroom situation with approximately six hours per week. Additionally, the students learn English mostly from textbooks and teachers' explanation. The information given is sometimes inauthentic and unsatisfactory to improve their English acquisition.

Students need additional sources to gain more information. One of the additional sources is using technology in the learning and teaching process. The example of using technology is by integrating the internet in the classroom. The internet refers to a global network which can connect all people around the world from one computer to another. Learning via internet accordance with the regulation of the Minister of Education and Culture No. 68 Year 2013 on the basic framework and curriculum structure of junior high school, the government develops the 2013 curriculum by introducing the changes of isolated learning patterns into networking learning patterns (learners can gain knowledge from anyone and from anywhere that can be contacted and obtained via the internet).

The advancement of integrating the internet in the teaching and learning process is called as web-based learning (Pachecho, 2005). Internet can be accessed everywhere and everytime. It can be used for supporting media in 
teaching and learning processes. The technology is able to enhance students' motivation in learning English, encourage autonomous learners, and deliver the information in the attractive way. Internet provides both teachers and students with authentic learning materials in the different formats (e.g. video, audio, picture, etc), and a place for idea sharing and meaning negotiation (Abdallah, 2010).

Responding to the fact that the internet can support teaching and learning processes and there are so many internet users in Indonesia, some schools start using the internet to gain its advantages. One of those schools is SMP Negeri 8 Medan. SMP Negeri 8 Medan has improved their Information Technology (IT) facilities specifically in internet properly. They have established a hot spot area and built a computer laboratory which is equipped with the Internet, so that both teachers and students can have free access to the internet to support the teaching and learning activities.

However, the use of the Internet in English teaching and learning processes in SMP N 8 Medan is not optimal enough. Both teachers and students there do not use internet as the school's expectation. The teachers seem hesitate and awkward in using computer laboratory and internet to support their teaching learning activities because there are many websites which contain learning materials in the internet but the materials doesn't meet with the learners' needs. Moreover, the contents of the web-based materials are also not relevant and appropriate with the basic competence in the national education curriculum in Indonesia. Then, most students there use the internet provided by school only for entertainment purposes, 
such as playing online games and accessing social network (Facebook, Instagram or Twitter).

Considering the facts above, this research is intended to develop a website which contains the materials and tasks which are appropriate for the students' needs, and the standard and the basic competence. This web site can be a supplementary or an additional source for teachers and students.

\section{REVIEW OF LITERATURE}

Web-Based Learning

Web-based learning is described as learning that is delivered wholly or in part via the internet. Web-based learning encompasses all educational interventions that make use of the internet or a local intranet (Cook, 2007:37). Web based learning is also called online learning or e-learning since it delivers online course content. E-learning is commonly referred to the intentional use of networked information and communications technology in teaching and learning (Naidu, 2006:1). Clark and Mayer (2003:10-11) describes e-learning in three aspects. The "e" refers to the "how" and the "learning" refers to what and why. The "how" means materials or courses in the form of the spoken or the printed texts and the pictures (illustrations, photos, animation, and video) are presented via computer. The "what" describes as the courses consist of the content (information) and the instructional method (techniques) which assist people learn it. The "why" defines as the courses are aimed to assist learners in achieving the learning objectives. Through flexible e- learning systems students would receive education anytime and anywhere that matches their own pace and learning styles. 
The idea of high quality learning experiences is not to move from teachercentered learning to technology-centered learning but rather to student-centered learning. Learning technologies should allow greater flexibility in supporting and enhancing learning experiences (Shankar, 2007:222).

Pacheco (2005:5-7) states that the use of the web-based learning in language classroom brings some added values. Students can develop autonomous learners. They can study independently online. They can learn by themselves with the teacher as their facilitator, course designers, and guidance in their learning. Webbased learning also provides flexibility in learning and teaching. Web-based learning supports the changing teacher-centeredness into student centeredness.

The web-based learning facilitates students to explore authentic materials or texts. It provides authentic use of English language (Pacheco, 2005:7). Students can practice grammar, reading, vocabulary, listening, etc directly by accessing many sites in the internet. It supports the students to be autonomous learners. The web-based learning can also improve students' motivation as well as engage students to involve and interact in the learning and teaching processes. The other advantages are facilitating to link resources in many different formats, delivering course materials in an efficient way, creating resources anywhere and anytime, and providing a useful sources of supplementary materials (McKimm et.al, 2003:872).

\section{Designing Website}

Design is the process of originating and developing a plan for an aesthetic and functional object, which usually requires considerable research, thought, modeling and iterative adjustment. With regard to the web, this involves the 
arrangement of content into graphical models that can be used as a basis for coding a site (Shane, 2006:20).

Beatrice (2011: 21-26) propose ADDIE model as a sequence for developing web pages, which is figured in figure below. The ADDIE model includes five stages: Analysis, Design, Development, Implementation and Evaluation.

\begin{tabular}{|c|c|c|c|c|}
\hline ANALISYS & DESIGN & DEVELOPMENT & IMPLEMENTATON & EVALUATION \\
\hline \multirow{3}{*}{$\begin{array}{l}\text { NEEDS } \\
\text { ANALLSYS } \\
\text { TARGET AUDIENCE } \\
\text { ANALISYS }\end{array}$} & LEARNING OBJECTINES & \multirow{2}{*}{$\begin{array}{l}\text { CONTENT } \\
\text { DEVELOPMENT }\end{array}$} & \multirow{2}{*}{$\begin{array}{l}\text { INSTALLATION } \\
\text { AND DISTRIBUTION }\end{array}$} & REACTIONS \\
\hline & SEOUENCING & & & LEARNINGS \\
\hline & INSTRUCTIONAL STRATEGY & $\begin{array}{l}\text { STORYBOARD } \\
\text { DEVELOPMENT }\end{array}$ & $\begin{array}{l}\text { MANAGING } \\
\text { LEARNER'S ACTIVITIES }\end{array}$ & $\overline{\text { BEHAVIOUR }}$ \\
\hline \multirow{2}{*}{$\begin{array}{l}\text { TASK ANDTOPIC } \\
\text { ANALLSYS }\end{array}$} & DELINERY STRATEGY & \multirow{2}{*}{$\begin{array}{l}\text { COURSENARE } \\
\text { DEVELOPMENT }\end{array}$} & & \multirow[t]{2}{*}{ RESULTS } \\
\hline & EVALUATION STRATEGY & & & \\
\hline
\end{tabular}

\section{Figure of Sequence for Developing Web-Pages}

These are the descriptions of the five stages in the ADDIE process:

1. Analysis

A needs analysis should be conducted at the start of any development. The needs analysis allows the identification of general, high-level course goals. Target audience analysis is another crucial step. Analysis also is needed to determine the course content.

\section{Design}

The design stage encompasses the following activities: formulating a set of learning objectives required to achieve the general, high-level course objective; defining the order in which the objectives should be achieved (sequencing); and selecting instructional, media, evaluation and delivery strategies. The outcome of 
the design stage is a course grid that will be used as a reference to develop the course. The course grid illustrates the curriculum structure (e.g. its organization in courses, units, lessons, activities); the learning objectives associated with each unit.

\section{Development}

In this stage, the e-learning content is actually produced. The content can vary considerably, depending on the available resources. For example, e-learning content may consist of only simpler materials (i.e. those with little or no interactivity or multimedia, such as structured PDF documents) which can be combined with other materials (e.g. audio or video files), assignments and tests. In that situation, storyboard development and the development of media and electronic interactions would not be conducted.

\section{Implementation}

At this stage the course is delivered to learners. The courseware is installed on a server and made accessible for learners. In facilitated and instructor-led courses, this stage also includes managing and facilitating learners' activities.

\section{Evaluation}

An e-learning project can be evaluated for specific evaluation purposes. You may want to evaluate learners' reactions, the achievement of learning objectives, the transfer of job related knowledge and skills, and the impact of the project on the organization.

Based on the explanation above, the process of designing appropriate webbased learning is divided into three stages i.e. preparation, development, and implementation step. In the preparation step, there are two stages which have to 
be completed before starting the website design. The first stage is analyzing students' needs including students' level of proficiency and students' characteristics and also see the basic and main competence given by the government. The second stage is making the course grid of materials based on the results of the needs analysis. In the development step, the website is designed. The first is making the story board of the website. Then, the developed materials can be inserted into the website. The next is inserting the images, media (audio, video, etc), and the interactive tools (chatting room, discussion boards, etc).

After the development step is done, the website is ready to be implemented in the learning and teaching process. This stage is called the implementation step. Before the website is fully implemented, the website has to be tested in the browser in order to know how well the website operates when it is published. After that, the website is ready to be uploaded. After the website has been released, there might be some comments and suggestions from the users (students). Finally, the last stage is revising the website based on users' (students') comments and suggestion and then uploading the latest revision of web-based learning site.

\section{RESEARCH METHOD}

The Design

This research applied Research and Development (R\&D). Borg and Gall (2003:569) defined R \& D as a development model which the findings of research are used to design new product and procedures. The step of doing this research followed the $R \& D$ cycles. It consisted of a cycle in which the product 
will be developed, field-tested, evaluated and refined until they meet specify criteria of effectiveness quality of similar standard.

The Data and Source of the Data

This study was carried out at the grade eight students of SMP Negeri 8 Medan which located in Jl. Turi No.96 Medan Kota. The data of this research are the results of the students' needs analysis and the result of expert judgment. The source of data are the students, and the validators.

\section{The Instrument}

The researcher get the data from questionnaire. There were two types of questionnaire used in this research i.e. the questionnaire for need analysis, the questionnaire for the expert judgment of material and media web-based. The organization of the questionnaires are presented below:

\section{a. Need analysis questionnaire}

The purpose of this questionnaire is to find out the target needs and the learning needs of the student in learning reading through website. In developing the needs analysis questionnaire, this study referred to the theory of needs assessment proposed by Hutchinson and Waters (1987) and Nunan (2004).

\section{b. Expert judgment of Material Questionnaire}

The expert judgment of materials questionnaire was distributed to the experts after the first draft materials were developed. The purpose of this questionnaire is to know the experts' opinions and suggestions towards the materials. The items of the materials questionnaire were adapted from the 
standardsof materials proposed by BNSP. While, the expert judgment of the website questionnaire was distributed to the experts after the first draft materials were developed. The purpose of this questionnaire was to know the experts' opinions and suggestions towards the media. The organization of the experts' judgment in terms of the website was presented below:

\section{Table of Expert Judgment of Media Questionnaire}

\begin{tabular}{|c|c|c|}
\hline No & The purpose of the question & References \\
\hline 1 & To find out the clarity of the goal of the website. & $\begin{array}{l}\text { Lever and Duffy } \\
(2009)\end{array}$ \\
\hline 2 & To find out the clarity of the website's information. & $\begin{array}{l}\text { Lever and Duffy } \\
\text { (2009) }\end{array}$ \\
\hline 3 & To find out that the website is welcoming and friendly. & $\begin{array}{l}\text { Lever and Duffy } \\
(2009)\end{array}$ \\
\hline 4 & To find out the consistency of the design. & $\begin{array}{l}\text { Lever and Duffy } \\
(2009)\end{array}$ \\
\hline 5 & To find out the organization of the design. & $\begin{array}{l}\text { Lever and Duffy } \\
\text { (2009) }\end{array}$ \\
\hline 6 & To find out the clarity of the navigation. & $\begin{array}{l}\text { Lever and Duffy } \\
\text { (2009) }\end{array}$ \\
\hline 7 & To find out that the navigation is easy to use. & $\begin{array}{l}\text { Lever and Duffy } \\
(2009)\end{array}$ \\
\hline 8 & To find out the appropriateness of the links. & $\begin{array}{l}\text { Lever and Duffy } \\
\text { (2009) }\end{array}$ \\
\hline 9 & To find out that the menu panel is easy to follow. & $\begin{array}{l}\text { Lever and Duffy } \\
\text { (2009) }\end{array}$ \\
\hline 10 & To find out the effectiveness of the picture placement. & $\begin{array}{l}\text { Lever and Duffy } \\
(2009)\end{array}$ \\
\hline 11 & $\begin{array}{l}\text { To find out the relation between the subject which is } \\
\text { taught and the website. }\end{array}$ & $\begin{array}{l}\text { Lever and Duffy } \\
(2009)\end{array}$ \\
\hline
\end{tabular}

\section{Research Procedures}

This study applied the theories of developing materials and the major steps of R\&D cycles (Gall, Gall, and Borg, 2003) and the ADDIE models as procedures of building a website from Beatrice (2011) were collaborated in conducting this research. The procedures were: 
1. Analysis

The need analysis aims to decide which materials that should be created in the website. The decision about which materials involved in this website were based on the result of the data gathered from the students and Standard of Competency and Basic Competency (SKKD).

2. Design

The design stage encompasses the following activities : formulating a set of learning objectives required to achieve the general, high-level course objective; defining the order in which the objectives should be achieved (sequencing); and selecting instructional, media, evaluation and delivery strategies.

3. Development

In this stage, the web-based content is actually produced. Story boarding is happen in this stage. Storyboarding is an activity in which the researcher designed the raw design of the product. This activity is necessary to make the website consistent and well organized.

4. Implementation

After the development step is done, the website is ready to be implemented in the learning and teaching process. At this stage the web-based material is delivered to learners. But the website has not perfect yet. The website has to be tested in the browser in order to know how well the website operates when it is published.

5. Evaluation 
The next step was obtaining the experts' judgment. The researcher use experts' judgment to validate the first draft. The input and revisions from the experts applied to revise and validate the first draft. Finally, the last stage is revising the website based on expert judgment and then uploading the latest revision of web-based learning site.

\section{DATA ANALYSIS, FINDINGS AND DISCUSSION}

Data Analysis

The findings covers the description about the target needs, and the learning needs.

Target Needs

The description of the target needs can be classified as three parts: necessities, lacks, and wants (Hutchinson and Waters, 1986). Necessities for junior high school students have been defined in standard competences and basic competences. In this study, the focus will be on the descriptive text for the eight grade students. The basic competence is 3.14 "Understand the social functions, generic structures, and linguistic features of narrative text as fable, according to the context of its use", and 4.18“Grasp the meaning of oral and written narrative text, in the form of short and simple fable in the use".

Lacks are the targets' gap between what they have already known (their current proficiency) and will know (the target proficiency). Researcher find the lack of the students that most participants (90.6\%) were confident with their reading skill and claimed that their reading skill is good. Then, participants have difficulties in reading. The difficulties is not only in a single area, but also in some other areas. The findings shows the main idea as the majority $(31.25 \%)$. 
Wants are the targets' needs in the learning seen from the targets' point of view. The majority of the participants $(43.7 \%)$ wanted to improve their vocabulary through the reading tasks. However, the other areas i.e. improve idea and organizing text (21.9\%) and mechanics improvement (12.5\%) are also considered. Meanwhile, targets' wants about the website show that more than $50 \%$ of the class, wanted a website which at least four colors combination. In short, they wanted a colorful website. Meanwhile, the other question shows that more than $70 \%$ of the students wanted menu panel at the top of the page. From this data, the researcher decided to accommodate the majority of the class i.e. put the menu panel at the top of the page.

\section{Learning Needs}

The description of the learning needs can be classified as five parts i.e. input, procedure, setting, teacher role, and learner role. Input refers to type of data which will be used in learning English. The findings shows what topics that participants want. From the data, it can be concluded that daily life (56.25\%), science and technology $(18.75 \%)$, and culture $(18.75 \%)$ are topics that the majority of the students are interested in. Consequently, the input in the website will use those topics. Then, previous question found out about what kind of input that participants wants. The data shows that $46.9 \%$ answers for that question is pictures, $25 \%$ is article from internet, and $15.6 \%$ is short stories. As a result, those three inputs were used as main input for the website.

Procedures specify what learners will actually do with the inputs that form the point of departure for the learning task. The activities that the targets want from this website are most of all options were considered as the activities in the 
media. There are 17 students $(22.37 \%)$ wanted to read a pictorial story in the learning activities. The other options are arrange jumbled paragraphs/sentences (14.47\%), answering short questions (13.16\%), completing sentences and read a text $(11.84 \%)$. The rests are read a paragraph/s (10.53\%), paraphrase paragraphs/texts $(7.89 \%)$, transforming ungrammatical sentences $(6.58 \%)$, and the last one is answer short question with options. Then all of the students thought that learning generic structures before reading is a must. Similar to the question number two, in the third question all targets agreed that before reading, it is necessary to learn genres of the text. 19 students said it is very important, meanwhile 13 students claimed that it is important.

The next analysis of learner needs is setting. Settings refer to the situation or condition in learning reading. the desired settings desired by the students to carry out the tasks. From the table, there were $65.62 \%$ of the students who wanted individual activity. Therefore, the activities in the developed website mostly will be carried out individually. In terms of the length of the texts the targets want to read, $43.57 \%$ of students claimed they can read at 200-300 words. Therefore the activities were suited with this situation. The last question about the setting was what kind of media that the targets want to use in reading. The data showed that $39.02 \%$ targets wanted to read via internet. It suited with the developed media i.e. a website and meant that the targets wrote their reading activities directly in the developed website.

Next was the analysis of teacher role. Teacher role refers to the types of functions teachers are expected to fulfill. The first question of teacher role was what the targets wanted the teacher did before starting the activities. 53.13\% 
students wanted some examples of the texts before the activities carried out. However, because this used online study, the teacher role in this part, i.e. giving examples of texts, was replaced by written instructions explanations, and examples. Then, half of the targets $(50 \%)$ wanted the teacher re-explained the materials if they had difficulties in the activities. The rests wanted their questions to be answered directly $(21.8 \%)$ and given more time to understand (18.75\%). Based on the table above, in the end of activities three quarters of students wanted the teacher to check and show their mistakes. However, the teacher also gave some feedbacks, only if necessary, for the students to improve their reading.

The last explanation is learner role. Learner role refers to what the learners need to do in completing the task. More than $50 \%$ of the students agreed that they wanted their peers to read, correct, review, and give feedback for their works. Therefore in the activities the students were asked to perform peer assessment.

\section{Findings}

The data above use as basis for developing the website. materials were developed from the course grid which was formulated based on the results of needs analysis and standards of competences and basic competences for the eight grade of junior high school students. The website consists of 5 pages, they are: Home, Start Up, Your Focus, Your Activity, Grammar Corner.

The first page of the website is Home. Home is the introductory page. This page presents the welcoming speech from the developer.

The second page is Start Up. The title of this page is "Let's Get Started". Under the title, there is a picture of some people holding a paper inscribed "What will you learn today?". By the title and the picture, the developer wants to inform 
the reader that the learning will be start in the next page. The basic competence, the learning material and the learning objective inserted in this page.

The next item is Your Focus. The learning materials of narrative text are presents in this page. It's conclude the definition, the generic structures, and language features. After the explanation about narrative, the example of narrative text also presents to make the students more understand about the materials. In order to meet the student's need in reading a pictorial story, the developer inserted some pictures related to the materials.

The fourth item is Your Activity. This page contains the activity or task for the students. There are three activities; Activity 1, Activity 2, Activity 3. All of the activity aimed to assess students comprehension about narrative text. The task about vocabularies inserted in the Activity 3. It purpose to enrich student's vocabulary.

The last item is Grammar Corner. As the name says, this section is functioned as a place for the students to learn the language focus they are; simple past tense as the tense for narrative text.The explanation about past tense are: the definition, the used, the formula, and the example in a sentence. So that the students will be more understand.

\section{Discussions}

The expert judgment was the next stage of this study after the website was developed. Then the product was evaluated and validated by two experts, first is an English lectureand an second is English teacher. This phase was conducted to know whether the materials were interesting, appropriate, and applicable for the 
grade VIII students of SMP Negeri 8 Medan. To obtain the experts judgment data, the researcher distributed the questionnaires to the validator.

Then, the results of the expert judgment questionnaire were analyzed using descriptive statistic. The central tendency which was applied in this study is the mean. In classifying the category, the mean was converted intofrequencies of agreement. The result of expert judgements presented in the following table:

\section{The Result of Expert Judgment of Materials}

\begin{tabular}{|c|c|c|c|c|}
\hline \multirow[t]{2}{*}{ No. } & \multirow[t]{2}{*}{ Statements } & \multicolumn{2}{|c|}{ Scores } & \multirow[t]{2}{*}{ Mean } \\
\hline & & Expert 1 & Expert 2 & \\
\hline 1. & $\begin{array}{l}\text { Materi yang disajikan dalam } \\
\text { website ini sesuai dengan standar } \\
\text { kompetensi dan kompetensi dasar } \\
\text { (2013). }\end{array}$ & 5 & 5 & 5 \\
\hline 2. & $\begin{array}{l}\text { Materi yang disajikan dalam } \\
\text { website ini menggunakan tata } \\
\text { bahasa yang baik dan benar. }\end{array}$ & 4 & 4 & 4 \\
\hline 3. & $\begin{array}{l}\text { Materi dalam website ini disajikan } \\
\text { dan disusun dengan menarik } \\
\text { sehingga dapat menambah motivasi } \\
\text { siswa untuk belajar. }\end{array}$ & 4 & 5 & 4.5 \\
\hline \multicolumn{2}{|c|}{ Total Score } & 13 & 14 & 13.5 \\
\hline \multicolumn{2}{|c|}{ Average Score } & 4.3 & 4.6 & 4.5 \\
\hline
\end{tabular}

Table above is the summary from the expert judgment questionnaire which covers three general items of contents appropriateness: the content, language, and materials presentation. It is shown that the mean value of the appropriateness of all aspects is 4.5. It is categorized as "Strongly Agree" as its positions is in the interval $4.20<\mathrm{x}<5.00$. The appropriateness had been approved by the materials experts as shown in table above.

Finally, the conclusion from the results above is that the materials in the website has reached the standards of appropriateness. The conclusion is based on 
the expert's opinion which indicates the agreement on the appropriateness of this unit based on the standards proposed by BNSP about learning materials for junior high school.

\section{The Result of Expert Judgment of Website}

\begin{tabular}{|c|c|c|c|c|}
\hline \multirow[t]{2}{*}{ No. } & \multirow[t]{2}{*}{ Statements } & \multicolumn{2}{|c|}{ Scores } & \multirow[t]{2}{*}{ Mean } \\
\hline & & $\begin{array}{c}\text { Expert } \\
1\end{array}$ & $\begin{array}{l}\text { Expert } \\
\quad 2\end{array}$ & \\
\hline 1. & Tujuan dari website jelas. & 4 & 4 & 4 \\
\hline 2. & $\begin{array}{l}\text { Terdapat keterangan dan informasi yang } \\
\text { jelas mengenai website. }\end{array}$ & 4 & 5 & 4 \\
\hline 3. & $\begin{array}{l}\text { Tampilan website bersahabat dan } \\
\text { menyenangkan. }\end{array}$ & 4 & 5 & 4.5 \\
\hline 4. & Desain dari website konsisten. & 4 & 4 & 4 \\
\hline 5. & $\begin{array}{l}\text { Desain dari website terorganisir dengan } \\
\text { baik. }\end{array}$ & 5 & 4 & 4.5 \\
\hline 6. & Navigasi website jelas. & 4 & 5 & 4.5 \\
\hline 7. & Navigasi website mudah digunakan. & 5 & 5 & 5 \\
\hline 8. & Semua link bekerja dengan baik. & 5 & 5 & 5 \\
\hline 9. & Pilihan menu mudah dipahami. & 5 & 5 & 5 \\
\hline 10. & Peletakan gambar pada website efektif. & 5 & 5 & 5 \\
\hline & $\begin{array}{l}\text { Terdapat keterangan mengenai mata } \\
\text { pelajaran apa yang dibahas di website. }\end{array}$ & 4 & 5 & 4.5 \\
\hline \multicolumn{2}{|c|}{ Total Score } & 49 & 52 & 50 \\
\hline \multicolumn{2}{|c|}{ Average Score } & 4.4 & 4.7 & 4.5 \\
\hline
\end{tabular}

Table above shows the mean value of the appropriateness of the website is

4.5. It is categorized as "Strongly Agree" as its positions is in the interval $4.20<\mathrm{x}$ $<5.00$. It can be seen that in terms of goal and the website information, the expert agreed that both of them are clear. It shows by the value 4 in those areas. Moreover, the expert also agreed that the website is welcoming and user-friendly. The table above shows the agreement of the expert that the design is consistent and well-organized. In addition, the expert also believed that the navigation is both clear and easy to use. It is shown by the values that reached $4.5-5.0$. Then, 
the expert believed that most of the links to other websites are working properly. The expert also agreed that the menu panel of the website is easy to follow and the pictures placement is effective. In addition, the expert also agreed that what subject the website relates to is clear.

Finally, the conclusion from the results above is that the website has reached the standards of good teaching and learning website according to Lever and Duffy's rubric (2009). The conclusion is based on expert's opinion which indicates the agreement based on the standards proposed by Lever and Duffy about academic website.

\section{CONCLUSIONS AND SUGGESTIONS}

Conclusion

Based on the findings and discussion, the students needed topic for learning reading. Daily lives, science and technology, and cultures are the topic they wanted. For the input, the students desired to have pictures, short stories, and articles from the Internet. The activities that the targets want from this website were read a story from pictures in the learning activities, answering short questions, completing sentences and reading paragraphs. The rests are arranging jumbled sentences, reading a text/s, transforming ungrammatical sentences, and the last one is paraphrasing. They also thought that learning grammar and genres were necessary before doing the activities. Then, the students felt that they were more comfortable doing the activities individually. The students thought that the Internet is the best media to read for them, it means that they want to read their reading directly in the website. The students also wanted some examples of the texts before the activities carried out. However, because this used online study, 
the teacher role in this part, i.e. giving examples of texts, was replaced by written instructions, explanations, and examples. The students also expected the teacher to check and show their mistakes. However, the teacher also gave some feedbacks, only if necessary, for the students to improve their reading. All these activities carried on in face to face situation. Lastly, the students agreed that they wanted their peers to read, correct, review, and give feedback for their works.

Then, the web-based reading learning that has developed are consist of five pages . They are: home, start up, your focus, your activity, and grammar corner. The site is http://readingenglish.webs.com/.

\section{Suggestions}

In accordance to the conclusion, the suggestions are proposed as the followings:

1. In the case of using website as media in learning English, to run itwell it is necessary for the English teacher to be able to understand how to use it.

2. Other researchers are expected to be able to develop website for other skills, grades, or semesters.

\section{References}

Abdallah, M. M. S. 2010. Web-based new literacies: Revisiting literacy in TESOL and EFL teacher education. Paper presented at the Australian Council of TESOL Associations (ACTA) International TESOL Conference held in Gold Coast, Australia 7-10 July, 2010

Badan Standar Nasional Pendidikan. 2011. Penilaian Buku Teks Pelajaran Bahasa Inggris SMP/MTs. Jakarta: Departemen Pendidikan Nasional

Clark, R. C., \& Mayer, R. E. 2003.E-learning and the Science of Instruction. SanFrancisco: Jossey-Bass 
Cook DA, Dupras DM. 2004. A practical guide to developing effective webbasedlearning. J Gen Intern Med;19:698-707

Diffily, Shane. 2006. The Website Manager's Handbook. Retrieved from $w w w . d i f f i l y . c o m / b o o k / w e b s i t e \_d e v e l o p m e n t . p d f$

Gall, J., Gall, M., \& Borg, W. (2003).Educational research: An introduction (7thed.). Boston: Pearson Education

Ghirardini, Beatrice. 2011. E-Learning methodologies: A guide for designing and developing e-learning courses. Rome: Food and Agriculture Organization of the United Nations

Hutchinson, T \& Waters, A. 1987.English for Specific Purposes: A Learning Centered Approach. Cambridge: University Press.

Lever-Duffy, J. \& McDonald, J. B. 2009.Teaching and Learning with Technology. Boston: Pearson

McKimm, et.al.2003.Web based learning in ABC of learning and teaching Medicine. London: BMJ Publishing Group Ltd.

Naidu, S. 2006. E-Learning: A guidebook of principles, procedures and practices (2nd Ed.). New Delhi: Commonwealth Educational Media Center for Asia(CEMCA)

Nunan, D. 1999. Second Language Teaching and Learning.Boston, MA: Heinle \& Heinle

Pacheco, A. Q. (2005). Web-based learning (WBL): a challenge for foreign language teachers .Revista Electrónica "Actualida des Investigativasen Educación", julio-diciembre, año/vol. 5, número 002 pp. 1-25. Universidad de Costa Rica:San José, Costa Rica

Shankar, T. (2007).Methods of Teaching Educational Technology. Delhi: Crescent Publishing Corporation 